Research Square
Preprints are preliminary reports that have not undergone peer review.

They should not be considered conclusive, used to inform clinical practice, or referenced by the media as validated information.

\title{
Rediscovering one's identity: A qualitative meta-synthesis study on the resilience experiences of family caregivers of patients with dementia
}

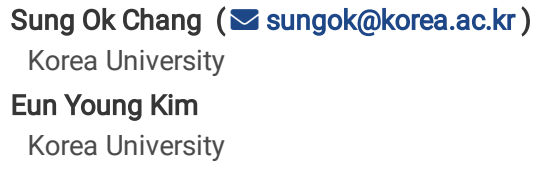

Research Article

Keywords: Dementia, Caregivers, Resilience, Psychological, Qualitative Research, Systematic Review

Posted Date: February 10th, 2022

DOI: https://doi.org/10.21203/rs.3.rs-1260102/v1

License: @ (i) This work is licensed under a Creative Commons Attribution 4.0 International License. Read Full License 


\section{Abstract}

Aims: To integrate the results of qualitative research on the resilience experiences of family caregivers for patients with dementia.

Design: A qualitative meta-synthesis study was conducted.

Methods: Five electronic bibliographic databases (PubMed, EMBASE, CINAHL, PsycINFO and Web of Science) were used in a comprehensive literature search. We used meta-ethnography methods and systematically reviewed.

Results: Through the process, three themes emerged: 'Seeing life as a caregiver as one's duty', 'Setting boundaries in life', 'Moving forward toward a developing life.' These themes illustrated how family caregivers of patients with dementia overcome the adversities they encounter.

Conclusion: This study shows the positive power of family caregivers of patients with dementia possess for overcoming their difficult situation. The results of this study suggest an important direction that can lead to positive ways to solve the problems of caring for dementia patients while reducing the suffering of caregivers and improving their quality of life.

\section{Introduction}

More than 55 million people worldwide have dementia, with nearly 10 million new cases occurring each year [1]. With the elderly population steadily increasing, the importance of dementia, considered to be the most important risk factor for aging populations [2], can only be expected to become more prominent in the future. Dementia is a disease caused by various disorders or injuries that affect the brain, such as Alzheimer's disease or stroke, resulting in cognitive impairment, which affects mental abilities very important for maintaining daily life, including memory, understanding, learning, language, and judgment [3]. Cognitive impairment generally accompanies or precedes changes in mood, emotion, control, and behavior [4]. Because their condition is a neurological disease accompanied by cognitive impairment, most dementia patients have no choice but to live as highly dependent beings [5].

It is estimated that $83 \%$ of dementia patients are cared for at home by unpaid caregivers such as family members. For example, in the United States, 11 million caregivers provide unpaid care to dementia patients [6]. Due to living with a significant burden of care, family caregivers suffer from physical problems such as cardiovascular disease and musculoskeletal symptoms [7,8] and mental problems such as stress, depression, and anxiety due to care [7,9,10]. This burden is negatively correlated with caregivers' quality of life [11], and ultimately, the quality of care provided to dementia patients [12]. In addition, it worsens patient's physical problems and causes serious social problems, such as abuse of dementia patients [13]. Therefore, we need to pay attention to the burdens of family caregivers of dementia patients, and research on protection strategies that can buffer the negative effects of those burdens is needed.

Resilience, an important concept for describing protection strategies in the study of caregivers, refers to the ability of a caregiver to adapt to the physical and psychological requirements of his or her role [14]. In some previous studies, family caregivers for patients with dementia were found to have high satisfaction with their caring roles and to have positive experiences despite the difficult situation, characteristics which were found to be related to resilience [14,15]. Resilience is a process of effectively negotiating, adapting or managing important causes of stress or trauma [16] and has been continuously studied for caregivers of patients with dementia. Their resilience has been shown to increase both their physical and mental well-being [17] while reducing their anxiety and depression and facilitating coping [18]. Recently, studies on the resilience of family caregivers caring for dementia patients have been increasing, but studies that can lead to a deeper understanding of that resilience by integrating previous studies' results have not yet been sufficiently undertaken. Moreover, there are some practical limits to understanding the resilience experiences of family caregivers of patients with dementia reported in previous studies due to the differences in study results. Therefore, this study integrates the results of various qualitative studies on the resilience of family caregivers of patients with dementia to formulate a new interpretation and reveal comprehensive aspects of the phenomenon. This can suggest future research directions and provide basic information for interventional research that can help reduce the difficulties of caregivers and improve the quality of care they provide to dementia patients. Ultimately, it will help improve the health and quality of life of dementia patients.

Qualitative meta-synthesis is a method of synthesizing and analyzing individual qualitative research, one that is used to derive more accumulated knowledge, expand on that knowledge and produce new interpretations from the results of research areas and phenomena suggested by existing studies [19,20]. In addition, it can enable more specific suggestions for future studies $[19,20]$.

To date, systematic reviews of the resilience of family caregivers for patients with dementia have been attempted in various ways [14,21,22], but a qualitative meta-synthesis done by analyzing the experiences of those caregivers from various perspectives has not been undertaken. Due to the nature of the concept of resilience, which reveals inner strength $[23,24]$, it is judged that it will be very meaningful to conduct a qualitative analysis that studies the resilience experiences of caregivers of patients with dementia.

\section{Aim}

The purpose of this study is to comprehensively understand in-depth the existing qualitative studies on the resilience experiences of family caregivers of patients with dementia by conducting a systematic review and qualitative synthesis.

\section{Design}

This study utilizes a qualitative meta-synthesis design that integrates and synthesizes qualitative research results exploring the experiences of family caregiver resilience in patients with dementia. From the existing qualitative meta-synthesis research methods, the seven phases of Nolit and Hare's meta- 
ethnography [25] were applied. This study was conducted in compliance with the guidelines of Enhancing transparency in reporting the synthesis of qualitative research statement (ENTREQ)[26].

The study's research question was:

- "What experiences do family caregivers of patients with dementia have in coping with the difficult situations they face?"

- "What is the strength that enables family caregivers of patients with dementia to overcome adversity?"

The study was registered in the international prospective register of systematic reviews (PROSPERO: CRD42021278764).

\section{Literature Search}

A literature search was conducted in November 2021. Five electronic bibliographic databases (PubMed, EMBASE, CINAHL, PsycINFO and Web of Science) were used to conduct a literature search. The search terms were selected from the MeSH term list ("caregivers", "family caregivers", "spouse caregivers", "qualitative research", "resilience, psychological" and "dementia") and were used in the search in different combinations with the Boolean operators "AND" and "OR". Publication years were not limited for the comprehensive literature searches.

The inclusion criteria applied to the research search were as follows: (a) studies aimed at examining the resilience experiences of family caregivers of patients with dementia, (b) studies published in peer-reviewed journals, (c) studies published in English and (d) studies that included participants older than 18 years.

The exclusion criteria were as follows: (a) studies not suitable for the purpose of this study, (b) studies not published in English, (c) studies in which qualitative methods were not used, (d) studies with children or adolescents and (e) systematic reviews, meta-syntheses, and secondary analyses.

We identified 665 studies and excluded 328 duplicates. After examining the study titles and abstracts to ensure that they met the inclusion criteria, we excluded 120 studies. After scrutinizing the full texts of the remaining 217 studies to assess their eligibility according to the inclusion criteria, we eliminated 206 studies. Eleven studies were chosen for the final review (see supplementary Table S1 for search strategies).

\section{Methods}

\section{Quality Appraisal}

To evaluate the quality of the 11 included studies, the Critical Appraisal Skills Programme (CASP) qualitative checklist, consisting of 10 questions, was used to evaluate each study's reliability, truthfulness and rigor [27]. Each of the two researchers evaluated each study using the CASP checklist, and any disagreements between the evaluations were resolved through discussion. As a result of the evaluation, three studies met $70 \%$ of the CASP criteria, three met $80 \%$ of the CASP criteria and four met $90 \%$ of the CASP criteria; no studies were excluded. The CASP results are presented in supplementary table S2

\section{Data extraction}

The two researchers read each study intensively and repeatedly to understand and familiarize themselves with the studies' details. The two researchers independently extracted data that were considered meaningful and relevant to the resilience experiences of family caregivers of patients with dementia, including author details, participant characteristics, research methods and citations, and organized them using a customized format in Microsoft Excel. The data were extracted into first-order constructs and second-order constructs. First-order constructs refer to the participants' interpretations in original studies, second-order constructs refer to the original researchers' interpretations and third-order constructs refer to the researchers' new interpretations concerning the first- and second-order constructs [19,20].

\section{Data synthesis}

Employing the meta-ethnography method, the researchers continuously contrasted and compared the first- and second-order constructs. To clarify the concept, key concepts were extracted from the first- and second-order constructs, and the third-order constructs, which are regarded as the main themes, were derived through a process of abstraction by the researchers [28]. During the process of analysis and synthesis, the researchers discussed and resolved differences in interpretation that arose due to differences in academic and clinical backgrounds.

\section{Ethical Approval}

This study is a literature review study, and ethical approval and informed consent were not required.

\section{Results}

Eleven studies that included 221 caregiver participants were included in the analysis (Table 1). One study was conducted in Australia, six in the United Kingdom and four in the United States. Of the participants, 117 (53\%) were spouses, 85 were children (38\%), 6 were grandchildren (3\%), 6 were significant others (3\%), 4 were siblings ( $2 \%)$ and 3 were friends (1\%). As a result of the synthesis of 11 qualitative literature analyses, 3 themes, 6 sub-themes was derived. 
Table 1

Summary of the included studies

Page $4 / 14$ 


\begin{tabular}{|c|c|c|c|c|c|c|c|c|c|}
\hline $\begin{array}{l}\text { Article. } \\
\text { No. }\end{array}$ & $\begin{array}{l}\text { Author, } \\
\text { year/Country }\end{array}$ & $\begin{array}{l}\text { Sample size } \\
(M: F)\end{array}$ & $\begin{array}{l}\text { Caregiver } \\
\text { age } \\
\text { range(years) }\end{array}$ & Type of caregiver (n) & Employment & $\begin{array}{l}\text { Caring } \\
\text { period } \\
\text { range } \\
\text { (years) }\end{array}$ & Research aim & $\begin{array}{l}\text { Research } \\
\text { design }\end{array}$ & $\begin{array}{l}\text { Data } \\
\text { coller } \\
\text { meth }\end{array}$ \\
\hline $\mathrm{A} 1$ & $\begin{array}{l}\text { O’Dwyer et } \\
\text { al., } 2013 \text { / } \\
\text { Australia }\end{array}$ & $9(4: 5)$ & $25-82$ & $\begin{array}{l}\text { Daughter (3), } \\
\text { Spouse(4), } \\
\text { Son-in-law (1), } \\
\text { Grandson (1) }\end{array}$ & $\begin{array}{l}\text { Part-time : } 3 \\
\text { Unemployed } \\
: 5 \\
\text { Job seeker } \\
: 1\end{array}$ & $0.5-11$ & $\begin{array}{l}\text { To conduct an } \\
\text { initial exploration } \\
\text { of carers' } \\
\text { experiences of } \\
\text { suicidality and } \\
\text { identify factors } \\
\text { associated with } \\
\text { risk and resilience, } \\
\text { which could be } \\
\text { used to guide } \\
\text { further research }\end{array}$ & $\begin{array}{l}\text { A } \\
\text { descriptive } \\
\text { qualitative } \\
\text { study }\end{array}$ & $\begin{array}{l}\text { In-de } \\
\text { inter }\end{array}$ \\
\hline $\mathrm{A} 2$ & $\begin{array}{l}\text { Donnellan et } \\
\text { al., 2015/UK }\end{array}$ & $20(7: 13)$ & $62-89$ & Spouse (20) & $\begin{array}{l}\text { Not } \\
\text { presented }\end{array}$ & $2-10$ & $\begin{array}{l}\text { To assess whether } \\
\text { spousal dementia } \\
\text { carers can } \\
\text { achieve resilience } \\
\text { and to highlight } \\
\text { which assets and } \\
\text { resources they } \\
\text { draw on to } \\
\text { facilitate or hinder } \\
\text { resilience, using an } \\
\text { ecological } \\
\text { framework }\end{array}$ & $\begin{array}{l}\text { A } \\
\text { qualitative } \\
\text { study }\end{array}$ & $\begin{array}{l}\text { In-de } \\
\text { intern }\end{array}$ \\
\hline A3 & $\begin{array}{l}\text { Donnellan et } \\
\text { al., } 2017 \text { / } \\
\text { UK }\end{array}$ & $23(7: 16)$ & $62-89$ & Spouse (23) & $\begin{array}{l}\text { Not } \\
\text { presented }\end{array}$ & $2-10$ & $\begin{array}{l}\text { to explore social } \\
\text { support as a key } \\
\text { component of } \\
\text { resilience to } \\
\text { identify the } \\
\text { availability, } \\
\text { function and } \\
\text { perceived } \\
\text { functional aspects } \\
\text { of support } \\
\text { provided to older } \\
\text { spousal dementia } \\
\text { carers }\end{array}$ & $\begin{array}{l}\text { A } \\
\text { qualitative } \\
\text { study }\end{array}$ & $\begin{array}{l}\text { In-de } \\
\text { inter }\end{array}$ \\
\hline A4 & $\begin{array}{l}\text { Roberts et } \\
\text { al., } \\
2018 / \text { USA }\end{array}$ & $33(4: 29)$ & $\begin{array}{l}\text { 39-83 } \\
\text { Median : } 61\end{array}$ & $\begin{array}{l}\text { Daughter, son, } \\
\text { daughter-in-law, son- } \\
\text { in-law : } 18 \\
\text { Wife : } 12 \\
\text { Husband : } 2 \\
\text { Sibling :1 }\end{array}$ & $\begin{array}{l}\text { Not } \\
\text { presented }\end{array}$ & $\begin{array}{l}\text { Not } \\
\text { presented }\end{array}$ & $\begin{array}{l}\text { To address this } \\
\text { major public health } \\
\text { challenge through } \\
\text { the lens of } \\
\text { caregiver } \\
\text { resilience } \\
\text { and caregiver } \\
\text { respite } \\
\text { programming }\end{array}$ & $\begin{array}{l}\text { A mixed- } \\
\text { method } \\
\text { study }\end{array}$ & $\begin{array}{l}\text { Face } \\
\text { face } \\
\text { inter }\end{array}$ \\
\hline A5 & $\begin{array}{l}\text { Jones et al., } \\
\text { 2019/UK }\end{array}$ & $\begin{array}{l}\text { 13(Not } \\
\text { presented) }\end{array}$ & $40-81$ & $\begin{array}{l}\text { Wife : } 6 \\
\text { Son :1 } \\
\text { Housemate :1 } \\
\text { Daughter :2 } \\
\text { Husband :2 } \\
\text { Daughter in law :1 }\end{array}$ & $\begin{array}{l}\text { Part-time : } 2 \\
\text { Retired : } 8 \\
\text { Full time : } 2 \\
\text { Not working } \\
: 1\end{array}$ & $\begin{array}{l}\text { Not } \\
\text { presented }\end{array}$ & $\begin{array}{l}\text { (a) explore } \\
\text { discrepancies and } \\
\text { congruency } \\
\text { between definitions } \\
\text { of resilience in the } \\
\text { academic literature } \\
\text { and carers own } \\
\text { conceptualisations; } \\
\text { (b) assess } \\
\text { differences and } \\
\text { similarities in } \\
\text { conceptualisations } \\
\text { of resilience } \\
\text { between carers } \\
\text { with high, medium } \\
\text { and low resilience } \\
\text { scores; (c) } \\
\text { compare carers' } \\
\text { perceived level of } \\
\text { resilience with the } \\
\text { level of resilience } \\
\text { when measured on } \\
\text { a standardized } \\
\text { tool. }\end{array}$ & $\begin{array}{l}\text { A cross- } \\
\text { sectional } \\
\text { qualitative } \\
\text { study }\end{array}$ & $\begin{array}{l}\text { Semi } \\
\text { stuct } \\
\text { inter }\end{array}$ \\
\hline A6 & $\begin{array}{l}\text { Donnellan et } \\
\text { al., 2018/UK }\end{array}$ & $13(4: 9)$ & $65-85$ & Spouse: 13 & $\begin{array}{l}\text { Not } \\
\text { presented }\end{array}$ & $3-13$ & $\begin{array}{l}\text { To examine } \\
\text { trajectories of } \\
\text { resilience and } \\
\text { which assets and } \\
\text { resources are }\end{array}$ & $\begin{array}{l}\text { A } \\
\text { qualitative } \\
\text { longitudinal } \\
\text { study }\end{array}$ & $\begin{array}{l}\text { In-de } \\
\text { inter }\end{array}$ \\
\hline
\end{tabular}




\begin{tabular}{|c|c|c|c|c|c|c|c|c|c|}
\hline \multirow[b]{2}{*}{ A7 } & \multirow[b]{2}{*}{$\begin{array}{l}\text { Han et al., } \\
\text { 2019/USA }\end{array}$} & \multirow[b]{2}{*}{$39(9: 30)$} & \multirow[b]{2}{*}{ Mean:62 } & \multirow[b]{2}{*}{$\begin{array}{l}\text { Adult child :82.1\% } \\
\text { Spouse/partner:7.7\% } \\
\text { Niece: } 5.1 \% \\
\text { Friend : } 5.1 \%\end{array}$} & \multirow[b]{2}{*}{$\begin{array}{l}\text { Full or part } \\
\text { time job : } 18 \\
\text { Not } \\
\text { employed: } \\
21\end{array}$} & \multirow[b]{2}{*}{$\begin{array}{l}6 \text { months } \\
\text { or less - } 3 \\
\text { years or } \\
\text { more }\end{array}$} & \multicolumn{3}{|l|}{$\begin{array}{l}\text { associated with } \\
\text { resilience and care } \\
\text { status transitions } \\
\text { in spousal } \\
\text { dementia carers }\end{array}$} \\
\hline & & & & & & & $\begin{array}{l}\text { To identify } \\
\text { challenges, } \\
\text { possible solutions } \\
\text { that are resources } \\
\text { for resilience, and } \\
\text { expected } \\
\text { consequences } \\
\text { from the } \\
\text { perspective of } \\
\text { family caregivers } \\
\text { of hospice patients } \\
\text { with dementia }\end{array}$ & $\begin{array}{l}\text { A theory- } \\
\text { driven, } \\
\text { deductive } \\
\text { content } \\
\text { analysis } \\
\text { study of } \\
\text { secondary } \\
\text { data } \\
\text { obtained } \\
\text { from a } \\
\text { clinical trial }\end{array}$ & $\begin{array}{l}\text { Indiv } \\
\text { inter }\end{array}$ \\
\hline A8 & $\begin{array}{l}\text { Conway et } \\
\text { al., 2020/UK }\end{array}$ & $\begin{array}{l}\text { 12(Not } \\
\text { presented }\end{array}$ & $\begin{array}{l}\text { Not } \\
\text { presented }\end{array}$ & Spouse/partner : 12 & $\begin{array}{l}\text { Not } \\
\text { presented }\end{array}$ & $\begin{array}{l}\text { 3month - } \\
6\end{array}$ & $\begin{array}{l}\text { To explore what } \\
\text { resilience means in } \\
\text { the context of } \\
\text { couplehood in } \\
\text { dementia, how } \\
\text { dyads experience a } \\
\text { shared sense of } \\
\text { resilience, how they } \\
\text { develop and } \\
\text { maintain resilience } \\
\text { and how this } \\
\text { impacts upon their } \\
\text { relationship }\end{array}$ & $\begin{array}{l}\text { A } \\
\text { qualitative } \\
\text { study }\end{array}$ & $\begin{array}{l}\text { In-de } \\
\text { inter }\end{array}$ \\
\hline A9 & $\begin{array}{l}\text { Jensen et al., } \\
\text { 2020/USA }\end{array}$ & $19(4: 15)$ & $20 s-80 s$ & $\begin{array}{l}\text { Child :7 } \\
\text { Grandchild : } 5 \\
\text { Spouse/significant } \\
\text { other : } 1 \\
\text { Sibling : } 2 \\
\text { Other family } \\
\text { member :3 } \\
\text { Friend : } 1\end{array}$ & $\begin{array}{l}\text { Not } \\
\text { presented }\end{array}$ & $\begin{array}{l}\text { Not } \\
\text { presented }\end{array}$ & $\begin{array}{l}\text { to identify } \\
\text { characteristics of } \\
\text { resilience using } \\
\text { surveys in } 50 \\
\text { bereaved } \\
\text { caregivers for } \\
\text { persons with } \\
\text { dementia who lost } \\
\text { their care recipient } \\
\text { in the past } 6 \text { month }\end{array}$ & $\begin{array}{l}\text { A } \\
\text { qualitative } \\
\text { descriptive } \\
\text { study }\end{array}$ & $\begin{array}{l}\text { Indiv } \\
\text { inter }\end{array}$ \\
\hline A10 & $\begin{array}{l}\text { Donnellan et } \\
\text { al., 2021/UK }\end{array}$ & $13(2: 11)$ & $47-81$ & $\begin{array}{l}\text { Adult daughters : } 6 \\
\text { Spouse : } 7\end{array}$ & $\begin{array}{l}\text { Not } \\
\text { presented }\end{array}$ & $1-9$ & $\begin{array}{l}\text { To identify the } \\
\text { factors that } \\
\text { facilitate or hinder } \\
\text { resilience in } \\
\text { spousal and adult } \\
\text { daughter carers, } \\
\text { and whether these } \\
\text { factors can be } \\
\text { mapped on to } \\
\text { ecological } \\
\text { resilience } \\
\text { framework }\end{array}$ & $\begin{array}{l}\text { A } \\
\text { qualitative } \\
\text { study }\end{array}$ & $\begin{array}{l}\text { Semi } \\
\text { struc } \\
\text { inter }\end{array}$ \\
\hline A11 & $\begin{array}{l}\text { Liu et al., } \\
\text { 2021/USA }\end{array}$ & $27(22 \%: 78 \%)$ & $50-89$ & $\begin{array}{l}\text { Spouse: } 46 \% \\
\text { Adult Children : } 50 \% \\
\text { Sibling:4\% }\end{array}$ & $\begin{array}{l}\text { Full-time or } \\
\text { part-time } \\
\text { employed : } \\
33.3 \% \\
\\
\text { Retired or } \\
\text { unemployed } \\
: 66.7 \%\end{array}$ & $\begin{array}{l}\text { Mean : } \\
2.48\end{array}$ & $\begin{array}{l}\text { To investigate the } \\
\text { resilience of a } \\
\text { growing but largely } \\
\text { underserved and } \\
\text { understudied } \\
\text { population- } \\
\text { Chinese American } \\
\text { dementia } \\
\text { caregivers }\end{array}$ & $\begin{array}{l}\text { A } \\
\text { qualitative } \\
\text { study }\end{array}$ & $\begin{array}{l}\text { Semi } \\
\text { struc } \\
\text { inter }\end{array}$ \\
\hline
\end{tabular}

F:female; M:male; CASP: Critical Appraisal Skills Programme checklist

Table 2.

Synthesized themes of resilience of family caregivers of patients with dementia 
Key concepts from first-and second order constructs

Past good memories $A 1, A 3, A 5, A 8, A 9$

Affection with family A2, A3, A4, A8, A10

Understanding about life of patients $\mathrm{A2}$, A7, A8, A10

Sharing experiences $\mathrm{A} 2, \mathrm{~A} 3, \mathrm{~A} 8, \mathrm{~A} 10$

Building trust relationships with patients $A 2, A 4, A 7, A 8, A 10$

Accepting the current situation $A 1, A 2, A 4, A 5, A 7, A 8, A 10$

Awareness of the finiteness of the situation A1, A2, A5, A8, A9

Expressing/controlling their own emotions $A 1, A 2, A 3, A 4, A 5, A 7$

Perceiving the value of their life $A 2, A 3, A 4, A 5, A 7, A 8$

Taking the situation positively $\mathrm{A} 1, \mathrm{~A} 2, \mathrm{~A} 5, \mathrm{~A} 6, \mathrm{~A} 8, \mathrm{~A}$, A10

Building a sense of unity from the same caregiver community

A1, A2, A3, A5, A6, A7, A8, A11

Getting help from their family $A 1, A 2, A 3, A 6, A 7, A 8, A 9, A 10$

Interacting with the community (social support) $A 1, A 2, A 3, A 5, A 6$,

A7, A8, A10, A11

Communicating with friends and neighbors $A 1, A 2, A 3, A 5, A 6, A 7, A 8$,

A9, A10

Receiving help from experts $\mathrm{A} 2, \mathrm{~A} 7, \mathrm{~A} 8$

Having personal time $A 1, A 2, A 4, A 5, A 6, A 7, A 9, A 11$

Striving for self-development A1, A2, A7, A11

Trying to maintain one's identity A1, A2, A5, A6, A7, A9, A11

Separating themselves from patient care $A 1, A 2, A 4, A 5, A 6, A 7, A 9$,

A10, A11

Focusing on the present $\mathrm{A} 2, \mathrm{~A} 4, \mathrm{~A} 5, \mathrm{~A} 10, \mathrm{~A} 11$

Recognizing the importance of rest $\mathrm{A} 1, \mathrm{~A} 2, \mathrm{~A} 4, \mathrm{~A} 5, \mathrm{~A} 6, \mathrm{~A} 10, \mathrm{~A} 11$

Staying work life A1, A4, A6, A8, A10

Doing one's role ${ }^{A 4, A 5, A 10, A 11}$

1. Maintaining sociality

. Finding stable life through help from supportive relationships

1. Setting boundaries in life
1. Seeing life as a caregiver as
one's duty

1. Seeing life as a caregiver as
one's duty with the patient
1. Building a sense of bonding based on life
1. Acknowledging their life as a caregiver
Synthesized themes

Taking one's responsibility A4, A5, A10, A11

Managing their routine activities $A 1, A 2, A 5, A 10, A 11$

Financial reward $\mathrm{A} 2, \mathrm{~A} 5, \mathrm{~A} 6, \mathrm{A7}, \mathrm{A} 8$

Learning professional knowledge $A 1, A 2, A 5, A 7$

Building confidence $\mathrm{A1}, \mathrm{A} 2, \mathrm{A4}, \mathrm{A} 5, \mathrm{~A} 7$

1. Developing professionalism in the role of a caregiver

Be active in life (as a caregiver) $\mathrm{A} 1, \mathrm{~A} 2, \mathrm{~A} 4, \mathrm{~A} 5, \mathrm{~A} 7$

Developing skills and insights $\mathrm{A} 1, \mathrm{~A} 2, \mathrm{~A} 4, \mathrm{~A} 5, \mathrm{~A} 7$

\section{\. Seeing life as a caregiver as one's duty}

Family caregivers of dementia patients developed bonds with patients based on their lives with the patients and acknowledged and accepted their roles as caregivers. They considered life as a caregiver a duty and tried to fulfill that duty. This sense of duty became the driving force behind their work as caregivers, and this became the basis for their overcoming difficult situations. 


\section{Building a sense of bonding based on life with the patient}

Good past memories $(A 1,3,5,8,9)$ made with patients with dementia and the affections shared with family members $(A 2,3,4,7,10)$ acted as positive forces when family caregivers had to cope with difficult situations. In their efforts to understand patients and their lives $(A 2,7,8,10)$, family caregivers found meaning in sharing their experiences $(A 2,3,8,10)$ and forming trusting relationships with their patients $(A 2,4,7,8,10)$, eventually building a sense of bonding. The formation of a sense of bonding provided justification for their roles as caregivers and became the basis for overcoming difficult situations.

We've been together nearly 50 years. Would I feel like this if I'd only been together 7, 8, 10?...... We're comfortable. We've been together for so long, so it couldn't be more comfortable. (A8).

My dad became acutely ill with aspirate pneumonia, so that we had 5 days as a family to come together. We kept a vigil so that he was never left alone, and most of the time there was more than one of us there 24/7. We had time together individually with him and as a family. Many memories and stories were shared in the middle of the night-I cherish that time (A9).

\section{Acknowledging their life as a caregiver}

The participants accepted their current situations, $(A 1,2,4,5,7,8,10)$ rather than complaining about the situation, recognizing that it was a finite one with an eventual end $(A 1,2,5,8,9)$. They tried to express their feelings without hiding them $(A 1,2,3,4,5,7)$, acknowledging the importance and value of their work $(\mathrm{A} 2,3,4,5,7,8)$ and of themselves. They perceived their situation positively and wanted to view their lives in a positive way $(\mathrm{A} 1,2,5,6,8,9,10)$.

I'm positive. I laugh and I sing and she laughs and I act gently in the house. I've even talked to one of my neighbours about my singing, and she said [Mr Go.] it's a good thing we've got a detached house. I sing at the top of my voice (A2).

'Doing what you can, if there's something you can't do, don't do it or do it differently. Look for the positives and don't beat yourself up (A5).

\section{冈. Setting boundaries in life}

Caregivers, who live a life in which the boundaries between their own lives and the lives of patients are ambiguous, set the boundaries of their lives. Rather than shouldering the difficult burdens of their lives alone, they actively sought supportive relationships. They wanted to focus on their own lives and lead independent lives.

\section{Finding a stable life through help from supportive relationships}

They realized that it would be more helpful to rely on different forms of support than to tackle their difficult situations alone. They found help by joining a local community or self-help group of people in the same situation, gaining solace from them, and forming a sense of unity $(A 1,2,3,4,6,7,8,11)$. They also received help from their families, who directly assisted with the act of caring while providing them psychological stability $(A 1,2,3,6,7,8,9,10)$. In addition, they sought social support from important acquaintances around them and received help $(A 1,2,3,5,6,7,8.10,11)$ While forming new social relationships, they maintained good social relations with friends and neighbors, from whom they received help $(A 1,2,3,5,6,7,8,9,10)$. They also got help from experts who can provide professional advice when they needed it $(\mathrm{A} 2,7,8)$. They did not hesitate to seek help and actively sought out the help available to them, and supportive relationships provided them with stability.

I [got] involved somehow with advocacy [for other carers]... I quickly became empowered...and then I was actually advocating for other people, so that was one way that I coped (A1).

Coming here(self-help group) has helped me because the people that come here are in the same position as I am. Some of them have been in it longer than me, so I can use their experience and I can relate to what they're saying (A2).

'The caregiver group is a godsend because sometimes you've just got to dump and you can do it there. It makes me feel better because I know I'm not alone. Every other one of those wives is going through what I'm going through. It's the neatest, tiredest looking group of women I've ever seen. We have days when we laugh and cry; it's like this little amount of light. Without the groups, I wouldn't have made it' (A4).

\section{Rediscovering an independent life}

By building their own lives and domains separate from their roles as caregivers, they were able to develop the strength to overcome the crisis of dealing with dementia. They tried to relieve their stress by spending personal time away from caring $(A 1,2,4,5,6,7,8,9,11)$. They focused on self-development $(A 1,2,7,11)$ and made efforts to maintain their individual identities $(A 1,2,5,6,7,9,11)$. To do this, caregivers focused on time $(A 2,4,5,10,11)$ and tried to make them feel separated from their time caring for the patient $(A 1,2,4,5,6,7,9,10,11)$, realizing the importance of rest and trying to secure the time necessary for sufficient rest $(\mathrm{A} 1,2,4,5,6,10,11)$. Creating temporal space for themselves in these ways was recognized as an effective method to cope with their difficult situations.

I love getting up in the morning at 5 am, going for my hour's walk, and that's my time ... that's my "clear my head" time. If I didn't have that right now, I think things would be different, but it's just giving me that little bit more strength to think straight (A1). 
I'm getting a respite on weekends. I really do know the meaning of recharging my batteries now. I feel more, you know, on Monday morning right, let's get on with the day (A2).

If I feel stressed, I sing loudly when taking a shower. ... I like singing old songs that were popular when I was young (A11).

\section{叉. Moving forward toward a developing life}

Caregivers tried not to become trapped in the work of caregiving. They sought to continue a life away from caregiving, maintaining their sociality while preserving their social positions. In addition, they tried to develop their skills as caregivers. Maintaining sociality and developing oneself were considered as one of the ways to hold on to their individual identities.

\section{Maintaining sociality}

Among the caregivers, there were those who had their own jobs other than the caregivers. They sought to maintain a social life and relationships (A1,4,6,8,10), while faithfully carrying out their assigned duties as caregivers $(A 4,5,10,11)$. They tried to manage their daily lives well $(A 1,2,5,10,11)$ and did their best in their responsibilities as caregivers $(A 4,5,10,11)$. They sometimes received financial rewards from social support services, communities of faith and other family members which were viewed as positive for handling their difficult situations $(A 2,5,6,7,8)$.

My brother-in-law moved her (mother-in-law) in with him to start with, but he worked during the day and I was concerned about her well-being during the day. I was afraid she was just eating Twinkies and things, not being able to prepare meals. I work from home, and I thought I could take care of her and work from home, so we brought her to our house (A4).

When I am at work......we'll have a laugh about it (working). I think going to work helps me a lot (A10).

\section{Developing professionalism in the role of caregiver}

They strived to acquire professional knowledge $(A 1,2,5,7)$, gained confidence in their work $(A 1,2,4,5,7)$, and tried to live an active life as caregivers $(A 1,2,4,5,7)$. They also did their best to develop skills and insights related to care $(\mathrm{A} 1,2,4,5,7)$.

I went on the internet, looked up what medication he should be on... and I was like a dog with a bone. We just became proactive. Within a couple of weeks I went to the Alzheimer's [support center] and I just sort of took on board everything. But it's 9 years later, and you're still learning all the time (A2).

I insist on exercising at home every day. Before he [care receiver] wakes up, I have some time to do that. If my health is poor, how can I take care of him? (A11).

\section{囚. The conceptual model of the resilience of family caregivers of patients with dementia}

The resilience experience of caregivers of patients with dementia can be expressed as Figure 2. Caregivers recognize a sense of duty as a caregiver through their bond with the patient and acknowledgement of the caregiver's life, and this sense of duty is the basis for their lives as caregivers. They also set boundaries between their own lives and their role as caregivers by seeking help from supportive relationships and pursuing an independent life. Caregivers plan and live a developing life based on this clarity in their lives. This series of processes can be expressed comprehensively as rediscovering one's identity..

\section{Discussion}

Paying attention to the difficulties and how to overcome the difficulties of family caregivers taking care of patients with dementia in an aging society is as important as paying attention to dementia patients. The results of our study can help understand the resilience of family caregivers of dementia patients by facilitating an understanding of how they overcame difficult situations. The two most noteworthy aspects about the resilience experiences of family caregivers of patients with dementia that were revealed through this study are that they want to separate their lives from that of their role as caregivers and that they greatly value living their own individual lives.

The importance they placed on their own lives was similar to that found in a study on caregivers of patients with chronic diseases [29], but this study differs from previous studies in that one of the characteristics of resilience it found is a seeking to further develop one's own life. Among the attributes of resilience, this seeking contains the meaning of growth $[30,31]$.

According to this study, family caregivers of patients with dementia were found to have many concerns and attachments in regard to their experiences related to resilience. They particularly valued familial affection and relationships and place importance on their relationships with patients. These results can be supported by those of previous studies that showed that the relationship with the patient and intimacy with the family had a positive effect on caregivers' abilities to overcome difficulties [21]. Based on these research results, we will be able to plan a family resilience promotion program with patients with dementia or their families to find the meaning of life, to help them form attachment to their lives and to improve relationships between families.

An additional characteristic that appeared in this study was that caregivers tried to acknowledge and accept their situation, recognizing that there was an end to the situation for which care must be provided. They worked to overcome the crisis by thinking about the value of life while remembering how important their role as caregiver was. Similar to the results of this study, a study on the resilience of chronic disease patients revealed that they sought to find meaning in their 
lives and to accept their situation positively to cope with their condition(s) [32]. Therefore, if we develop a program to improve the resilience of caregivers for patients with dementia by reflecting their needs to find and realize the value of life, positive results can be expected.

Caregivers were not reluctant to receive help, actively seeking out organizations and methods from which they could receive help. In a previous study, it was determined that the longer the time of caregiving, the greater the burden became for family caregivers of dementia patients [33]. Providing direct and indirect support will make it possible to reduce the burden of care on the families of dementia patients. Medical experts need to identify the needs of these family caregivers in order to help them and to develop specific measures so that they can receive appropriate support. For this, policy discussions will be necessary.

In this study, caregivers tried to overcome difficult situations by reserving time to focus on their own lives separate from their lives as caregivers. This can be interpreted similarly to previous studies which reported that absenting oneself from the difficult situation and developing a good coping strategy had positive effects on reducing stress and depression [21,34]. Therefore, medical professionals need to develop realistic alternatives that allow family caregivers of patients with dementia to be separated from their caregiver life and have more time to focus on their own lives.

Family caregivers wanted to move forward toward an evolving life, even if they were in a difficult situation. They wanted to maintain their jobs, fulfill their roles and responsibilities as caregivers, and sustain their daily routines. In addition, financial compensation from social support services, communities of faith and other family members was a helpful factor for them. In previous studies, family caregivers underwent negative psychological experiences, such as worsening mental health and increasing life stress levels, due to job instability including unemployment and turnover [35]. Therefore, the results of this study implies methods of reducing their burden of care, which is interpreted as having an important meaning in the resilience of family caregivers of dementia patients Moreover, this supports the previous research that growth and development are the main attributes of resilience [30,31]. Based on these characteristics of resilience of family caregivers for patients with dementia, it is necessary to develop and provide various platforms so that they can develop their expertise. Their will for growth can change the paradigm for future family caregivers for patients with dementia, and they can grow as a professional group with a new specialty. Such a positive movement could provide an important solution to the social difficulties related to caring for patients with dementia.

Through this study, we were able to confirm the resilience experience of caregivers of patients with dementia and to understand them in depth. This study can provide basic data for developing a resilience promotion program for caregivers of dementia patients and can suggest directions for ways to reduce caregivers' difficulties and improve their quality of life. In addition, it can provide basic data for the development of educational programs for medical professionals who provide counseling and education for the caregivers of dementia patients.

\section{Limitations}

In this study, it was found that family caregivers consisted of various family members, with the percentage of spouses the highest at $53 \%$. However, since different family member caregivers are included in our sample, it was difficult to distinguish the characteristics of spouse caregivers' resilience experiences. Therefore, it is necessary to conduct separate studies in more detail on the resilience of spouse caregivers and the resilience of children caregivers in the future to identify the characteristics of each. In addition, this study did not specify whether each family caregiver lived with their patients with dementia. In order to consider the quality of life of family caregivers and their lives separately from that of caregivers, it will be necessary in the future to study the resilience of family caregivers according to whether they live together with their patients.

\section{Conclusion}

As resilience is a positive force for overcoming crisis, understanding the resilience of caregivers for dementia patients is a very important cornerstone for designing a positive future for them and their patients. The experiences of resilience of family caregivers for patients with dementia present evidence for and directions on what medical professionals should do to ease their burdens and to assist them in their efforts. In order to prepare an alternative to caring for dementia patients, which is a socially important issue, it is necessary to raise the awareness that the resilience of a family caregiver is a very important concept. Measures to improve resilience should be discussed in policy and realized in detail, and for this, the efforts of medical experts and leaders will be required.

\section{Declarations Conflicts of interest}

No conflicts of interest have been declared by the authors.

\section{Competing interests}

No conflicts of interest have been declared by the authors.

\section{Ethics approval and consent to participate}

Not applicable

\section{Consent for publication}


Not applicable

\section{Availability of data and material}

All data generated or analyzed during this study is included in this published article

\section{Funding}

This study was supported by a National Research Foundation of Korea grant funded by the Korea government (NRF-2021R1I1A1A01048956).

\section{Author contributions}

Conceived and designed the study : EYK, SOC

Performed the data collection : EYK, SOC

Analyzed the data: EYK, SOC

Contributed materials : EYK, SOC

Wrote the first draft of the manuscript : EYK, SOC

Agree with manuscript results and conclusion : EYK, SOC

Prepared figures 1,2 \& Table 1,2 : EYK

All authors reviewed the manuscript

Acknowledgments

This study was supported by a National Research Foundation of Korea grant funded by the Korea government (NRF-2021R1/1A1A01048956).

\section{References}

1. World Health Organization. Dementia. 2021. https://www.who.int/news-room/fact-sheets/detail/dementia Accessed 8 Jan 2022

2. Arvanitakis Z, Shah RC, Bennett DA. Diagnosis and Management of Dementia: Review. JAMA. 2019;322(16):1589-99. https://doi.org/10.1001/jama.2019.4782

3. Atri A. The Alzheimer's disease clinical spectrum. Medical Clinics. 2019;103(2): 263-96. https://doi.org/10.1016/j.mcna.2018.10.009

4. Reynolds GO, Willment K, Gale SA. Mindfulness and cognitive training interventions in mild cognitive impairment: Impact on cognition and mood. Am J Med. 2021;134(4): 444-55. https://doi.org/10.1016/j.amjmed.2020.10.041

5. Abreu W, Rodrigues T, Sequerira C, Pires R, Sanhudo A. The experience of psychological distress in family caregiver of people with dementia: A crosssectional study. Perspect Psychiatr Care. 2018;54:317-23. https://doi.org/10.1111/ppc.12240

6. Alzheimer's Association. 2021 Alzhemer's disease facts and figures. 2021. https://www.alz.org/media/documents/alzheimers-facts-and-figures.pdf Accessed 7 Jan 2022

7. Richardson TJ, Lee SJ, Berg-Weger M, Grossberg GT. Caregiver health: health of caregivers of Alzheimer's and other dementia patients. Curr Psychiatry Rep. 2013;15(7):367. https://doi.org/10.1007/s11920-013-0367-2

8. Levenson RW. Stress and illness: A role for specific emotions. Psychosom Med. 2019;81(8):720-30. https://doi.org/10.1097/PSY.0000000000000736

9. Sun Y, Lwagami M, Watanabe T, Sakata N, Sugiyama T, Miyawaki A, Tamiya N. Factors associated with psychological distress in family caregivers: Finding from nationwide data in Japan. Geriatr Gerontol Int. 2021;21(9):855-64. https://doi.org/ 10.1111/ggi.14250

10. Medrano M, Rosario RL, Payano AN, Capellan NR. Burden, anxiety and depression in caregivers of Alzheimer patients in the Dominican Republic. Dement Neuropsychol. 2014;8(4):384-8. https://doi.org/10.1590/S1980-57642014DN84000013

11. Tulek Z, Baykal D, Erturk S, Bilgic B, Hanagasi H, Gurvit IH. Caregiver burden, quality of life and related factors in family caregivers of dementia patients in Turkey. Issues Ment Health Nurs. 2020;41(8):741-9. https://doi.org/10.1080/01612840.2019.1705945

12. Nasrun MWS, Kusumaningrum P, Redayani P, Lahino HL, Mardhiyah FS, Basfiansa AD, Nadila N. Relationship between quality of life people with dementia and their caregivers in Indonesia. J Alzheimers Dis. 2021;81(3):1311-20. https://doi.org/ 10.3233/JAD-201550

13. Gimeno I, Val S, Moreno MJC. Relation among caregivers' burden, abuse and behavioural disorder in people with dementia. Int J Environ Res Public Health. 2021;18(3):1263. https://doi.org/10.3390/ijerph18031263

14. McKenna O, Fakolade A, Cardwell K, Langlois N, Jiang K, Pilutti LA. Towards conceptual convergence: a systematic review of psychological resilience in family caregivers of persons living with chronic neurological conditions. Health Expect. 2021; Online ahead of print. https://doi.org/10.1111/hex.13374 
15. Dias R, Santos RL, de Sousa B, Nogueira MML, Torres B, Belfort R, Dourado MCN. Resilience of caregivers of people with dementia: a systematic review of biological and psychosocial determinants. Trends Psychiatry Psychother. 2015; 37(1):12-9. https://doi.org/ 10.1590/2237-6089-2014-0032

16. Windle G. What is resilience? A review and concept analysis. Rev Clin Gerontol. 2011;21(2):152-69. https://doi.org/10.1017/S0959259810000420

17. Sarabia-Cobo C, Sarria E. Satisfaction with caregiving among informal caregivers of elderly people with dementia based on the salutogenic model of health. Appl Nur Res. 2021;62:151507. https://doi.org/10.1016/j.apnr.2021.151507

18. Yang Z, Jia H, Lu Y, Liu S, Dai M, Zhang H. Prevalence and related factors of depression and anxiety in a cohort of Chinese elderly caregivers in the nursing home. J Affect Disord. 2021;295:1456-61. https://doi.org/ 10.1016/j.jad.2021.09.026

19. Cahill M, Robinson K, Pettigrew J, Galvin R, Stanley M. Qualitative synthesis: A guide to conducting a meta-ethnography. Br J Occup Ther. 2018;81(3):129-37. https://doi.org/10.1177/0308022617745016

20. Toye F, Seers K, Allcock N, Briggs M, Carr E, Barker K. Meta-ethnography 25 years on: challenges and insights for synthesizing a large number of qualitative studies. BMC Med Res Methodol. 2014;14:80. https://doi.org/10.1186/1471-2288-14-80

21. Teahan A, Laffery A, McAuliffe E, Phelan A, O'Sullivan L, O'Shea D, Fealy G. Resilience in family caregiving for people with dementia: A systematic review. Int J Geriatr Psychiatry. 2018;33(12):1582-95. https://doi.org/10.1002/gps.4972

22. Petriwskyj A, Parker D, O’Dwyer S, Moyle W, Nucifora N. Interventions to build resilience in family caregivers of people living with dementia: a comprehensive systematic review. JBI Database System Rev Implement Rep. 2016;14(6):238-73. https://doi.org/10.11124/JBISRIR-2016-002555

23. Wang L, Tao H, Bowers BJ, Brown R, Zhang Y. Influence of social support and self-efficacy on resilience of early career registered nurses. West $\mathrm{J}$ Nur Res. 2017;40(5):648-64. https://doi.org/10.1177/0193945916685712

24. Connor KM, Davidson JRT. Development of a new resilience scale: The Connor-Davidson Resilience Scale (CD-RISC). Depress Anxiety, $2003 ; 18(2): 76-82$. https://doi.org/10.1002/da.10113

25. Noblit GW, Hare RD. Meta-ethnography: Synthesizing qualitative studies. Thousand Oaks, CA: Sage.Publications. 1988.

26. Tong A, Flemming K, McInnes E, Oliver S, Craig J. Enhancing transparency in reporting the synthesis of qualitative research: ENTREQ. BMC Med Res Methodol. 2012;12:181. https://doi.org/10.1186/1471-2288-12-181

27. Critical Appraisal Skills Programme. CASP (Qualitative) checklist. 2018. https://casp-uk.net/wp-content/uploads/2018/01/CASP-Qualitative-Checklist2018.pdf/. Accessed 15 Dec 2021.

28. Sattar R, Lawton R, Panagioti M, Johnson J. Meta-ethnography in healthcare research: A guide to using a meta-ethnographic approach for literature synthesis. BMC Health Serv Res. 2021; 21(1):50. https://doi.org/10.1186/s12913-020-06049-w

29. Kim EY, Oh S, Son Y-J. Caring experiences of family caregivers of patients with heart failure: A meta-ethnographic review of the past 10 years. Eur $\mathrm{J}$ Cardiovasc Nurs. 2020;19(6):473-85. https://doi.org/10.1177/1474515120915040

30. Babanataj R, Mazdarani S, Hesamzadeh A, Gorji MH, Cherati JY. Resilience training: Effects on occupational stress and resilience of critical care nurses. Int J Nurs Pract. 25(1):e12697. https://doi.org/10.1111/ijn.12697

31. Kim EY, Lee YN, Chang SO. How do patients on hemodialysis perceive and overcome hemodialysis?: Concept development of the resilience of patients on hemodialysis. Nephrol Nurs J. 2019;46(5):521-30

32. Kim EY, Lee YN, Chang So. Exploring subjective frames of patients on hemodialysis on acquiring resilience: A Q methodology study. Nephrol Nurs J. 2018;45(4):357-68.

33. Pudelewicz A, Talarska, D, Bączyk G. Burden of caregivers of patients with Alzheimer's disease. Scand J Caring Sci. 2019;33(2):336-41. https://doi.org/10.1111/scs. 12626

34. Sequeira C. Difficulties, coping strategies, satisfaction and burden in informal Portuguese caregivers. J Clin Nurs. 2013;22(3-4):491-500. https://doi.org/ $10.1111 /$ jocn. 12108

35. Li L, Lee Y. Employment adjustment and mental health of employed family caregivers in Canada. Aging Ment Health. 2020;24(12):2073-81. https://doi.org/10.1080/13607863.2019.1647136

\section{Figures}




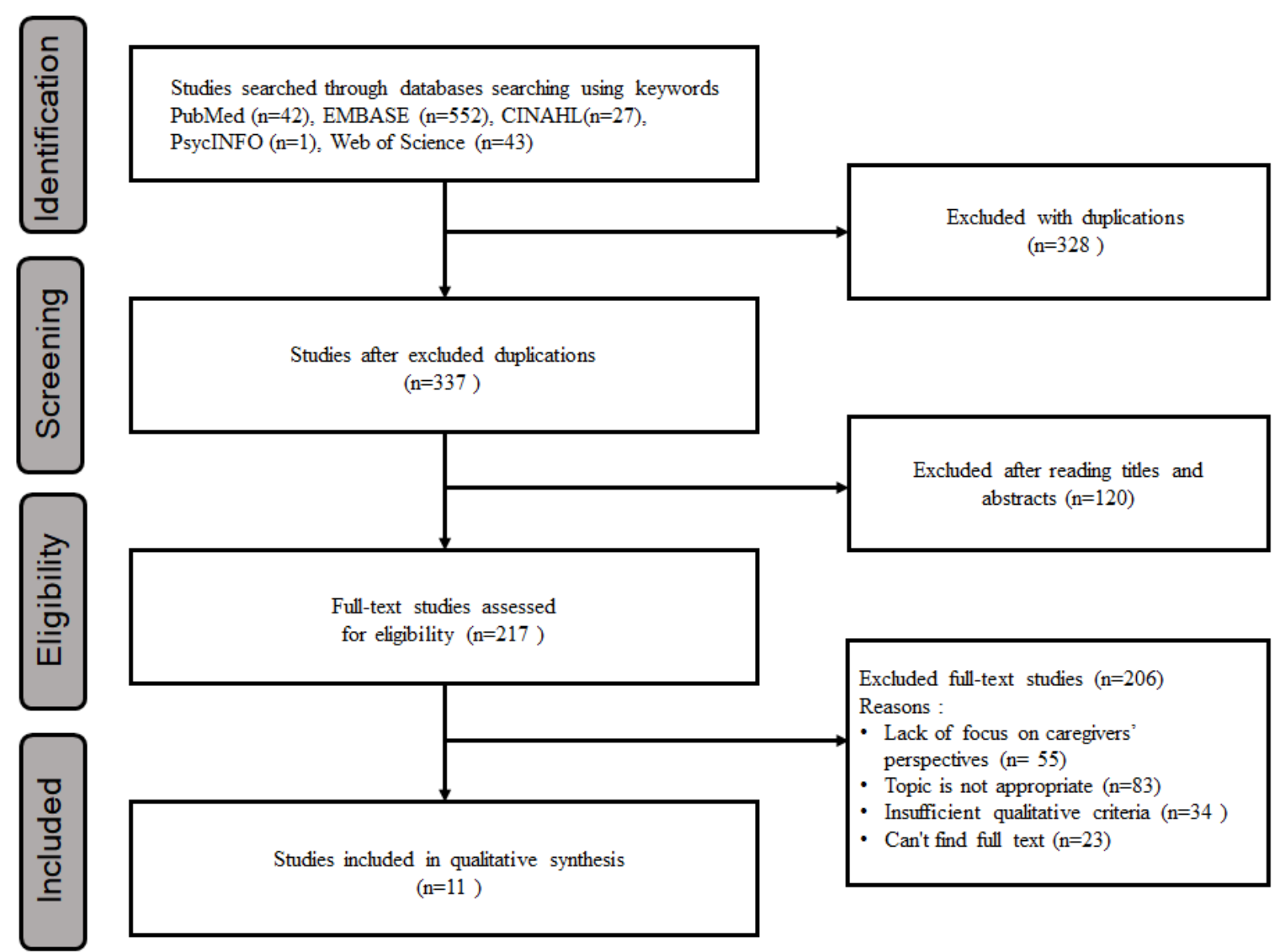

Figure 1. Flow Chart of Systematic Review of Literature Selection Process

Figure 1

Please See image above for figure legend.

\section{Finding identity of life}

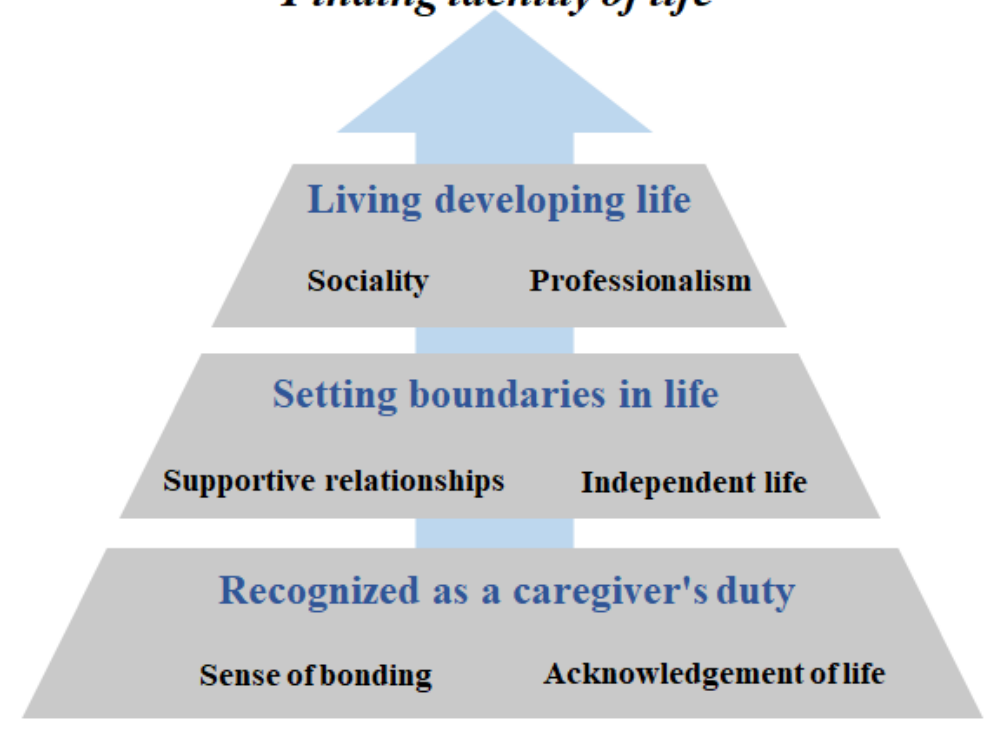

Figure 2. The Conceptual Model of the Resilience of Family Caregivers of Patients with Dementia

Figure 2

Please See image above for figure legend. 


\section{Supplementary Files}

This is a list of supplementary files associated with this preprint. Click to download.

- SupplemantaryTableS1S20114.docx 